\title{
Inhibition of IGF-1 receptor kinase blocks the differentiation into cardiomyocyte-like cells of BMSCs induced by IGF-1
}

\author{
HAIBIN GONG, XIULI WANG, LEI WANG, YING LIU, JIE WANG, QIAN LV, \\ HUI PANG, QINGLIN ZHANG and ZHENQUAN WANG \\ Department of Cardiology, Xuzhou Central Hospital, Xuzhou Cardiovascular \\ Disease Institute, Xuzhou, Jiangsu 221009, P.R. China
}

Received June 9, 2016; Accepted March 21, 2017

DOI: $10.3892 / \mathrm{mmr} .2017 .6639$

\begin{abstract}
Bone marrow mesenchymal stem cells (BMSCs) have the potential to transdifferentiate into cardiomyocyte-like cells (CLCs) if an appropriate cardiac environment is provided. Insulin-like growth factor-1 (IGF-1) plays an important role in the cell migration, survival and differentiation of BMSCs. However, the effect of IGF-1 on the cellular differentiation remains unclear. In the present study, BMSCs were isolated from rat femurs and tibias and the cells were purified at passage 6 (P6). IGF-1 and IGF-1 receptor (IGF-1R) kinase inhibitor I-OMe AG538 were added to detect if IGF-1 could induce BMSCs to transdifferentiate into CLCs and if I-OMe AG538 could inhibit IGF-1-mediated receptor activation and downstream signaling. Immunostaining demonstrated that all P6 BMSCs express CD29 and CD44 but not CD45. BMSCs induced by $15 \mathrm{ng} / \mathrm{ml} \mathrm{IGF}-1$ revealed positivity for cardiac troponin-T and cardiac troponin-I. The optimal induction time was 14 days but the expression of these proteins were incompletely inhibited by $300 \mathrm{nmol} / 1 \mathrm{I}-\mathrm{OMe}$ AG538 and completely inhibited by $10 \mu \mathrm{mol} / 1 \mathrm{I}-\mathrm{OMe}$ AG538. Western blotting showed that the level of IGF-1R autophosphorylation and the expression of cTnT and cTnI were higher when BMSCs were induced for 14 days. I-OMe AG538 selectively inhibited IGF-1-mediated growth and signal transduction and the inhibitory effect of I-OMe AG538 were not reverted in the presence of exogenous IGF-1. In addition, when a time course analysis of the effects of I-OMe AG538 on mitogen-activated protein kinase kinase and phosphatidylinositol 3-kinase signaling were done, we observed a transient inhibitory effect on Erk1/2 and Akt phosphorylation, in keeping with the inhibitory effects on cell growth. Taken together, these data indicate that I-OMe AG538 could inhibit IGF-1-induced CLCs in BMSCs and this effect is time- and concentration-dependent.
\end{abstract}

Correspondence to: Dr Haibin Gong, Department of Cardiology, Xuzhou Central Hospital, Xuzhou Cardiovascular Disease Institute, 199 Jiefang Road, Xuzhou, Jiangsu 221009, P.R. China

E-mail: gong_haibin1@163.com

Key words: BMSCs, myocardial microenvironment, differentiation, CLCs, IGF-1, inhibitor, signal transduction

\section{Introduction}

Bone marrow mesenchymal stem cells (BMSCs) have the potential to transdifferentiate into cardiomyocyte-like cells (CLCs) in the heart and appear as functional phenotypes of myocardial cells (1-3). It has been of great interest in treatment of myocardial infarction to use stem cells to prevent deterioration of heart failure and even to repair the damaged myocardium. It has been reported that growth factors added to the local microenvironment can improve the survival rate and functioning of the transplanted cells $(4,5)$.

Insulin-like growth factor-1 (IGF-1) is a potent mitogen that has been proposed to play an important role in the regulation of cell proliferation, apoptosis, and tumorigenicity (6-8). The IGF-1 receptor (IGF-1R) and the insulin receptor are structurally highly related glycoproteins. Both these receptors possess two extracellular $\alpha$-subunits, which bind the ligand and two $\beta$-subunits. The receptors also span the membrane and possess the intracellular autophosphorylation sites. IGF-1 is involved in normal cell proliferation and has been implicated in oncogenesis. The IGF-1 ligand, its receptor, the IGF-1 binding proteins, and the specific proteolytic enzymes which degrade these proteins constitute an important regulatory system which plays a pivotal role in normal and neoplastic cell growth (9). It has been reported that IGF-1 promotes migration of endothelial cells and cardiac resident progenitor cells (10-13). Li et al (4) also found that IGF-1 can simulate transdifferentiation of BMSCs into the cardiac phenotype and enhance the expression of GATA-4, but the mechanism is not clear.

In the present study, BMSCs were isolated from rat femurs and tibias and the cells were purified at passage 6 (P6). IGF-1 and IGF-1R kinase inhibitor I-OMe AG538 were added to detect if IGF-1 could induce BMSCs to transdifferentiate into CLCs and if I-OMe AG538 could inhibit IGF-1-mediated receptor activation and downstream signaling. Our study shows that I-OMe AG 538 could inhibit IGF-1-induced CLCs in BMSCs.

\section{Materials and methods}

Isolation and culture of BMSCs. BMSCs were isolated according to the method described by Panepucci et al (14). In brief, femurs and tibias from SD rats (male, weighing 150 $\pm 5 \mathrm{~g}$ ) 
were removed. Muscle and extraosteal tissue were trimmed under sterilized conditions. Bone marrow cells were flushed and were transferred into culture flasks in $5 \% \mathrm{CO}_{2}$ incubator at $37^{\circ} \mathrm{C}$. The culture medium contained $10 \%$ fetal calf serum (FCS), (HyClone, Tauranga, New Zealand) and DMEM/F12 (Gibco, Grand Island, NY,USA) containing 100 U/ml penicillin, $100 \mathrm{mg} / \mathrm{ml}$ streptomycin, $2 \mathrm{mM}$ L-glutamine (Sigma-Aldrich, St. Louis, MO, USA). Three days later, BMSCs adhered to the bottom of culture plates, and the hematopoietic cells remained suspended in the medium. Fresh medium was changed every 3 days. The sub-confluent cells in the seed cultures were removed from the flasks by 0.25 trypsin (Sigma-Aldrich) treatment 7 days after the initial plating. They were labeled as P1 and continued to culture until P6.

Drugs. I-OMe AG538 was purchased from Sigma-Aldrich. Stock solution of this drug was prepared in DMSO and stored at $-20^{\circ} \mathrm{C}$. Working dilutions of all drugs were prepared immediately before use.

In vitro cytotoxicity. To study the inhibition effects of I-OMe AG538 in standard or no-serum medium, 1,000-10,000 cells were plated into 96-well plates in DMEM/F12 plus $10 \%$ FCS. After $24 \mathrm{~h}$, medium was replaced by DMEM/F12 plus $10 \%$ FCS or without (control) various concentrations of the compound $(10 \mathrm{nmol} / \mathrm{l}-100 \mu \mathrm{mol} / \mathrm{l})$ for $\leq 3$ days. MTT solution was added to the plate $(5 \mathrm{mg} / \mathrm{ml}) 20 \mu \mathrm{l} /$ well, then incubated for $4 \mathrm{~h}$ and washed. In order to monitor at OD $490 \mathrm{~nm}, 150 \mu \mathrm{l}$ DMSO was added to the plate for $10 \mathrm{~min}$. $\mathrm{IC}_{50}$ (drug concentration resulting in 50\% inhibition of growth) values of inhibitor was determined using the GraphPad Prism 5 Demo program, GraphPad Software, Inc. (La Jolla, CA, USA).

Immunocytochemical staining. When BMSCs were cultured at P6, they were already purified. To identify if these cells were BMSCs, cells cultured on $35 \mathrm{~mm}$ culture dish were fixed with $4 \%$ paraformaldehyde for $20 \mathrm{~min}$. After being washed 3 times with PBS for $5 \mathrm{~min}$, the culture dish was covered with $0.01 \%$ Triton X-100 (Gen-View Scientific, Inc., El Monte, CA, USA) for $10 \mathrm{~min}$ then were covered with $3 \% \mathrm{H}_{2} \mathrm{O}_{2}$ for $10 \mathrm{~min}$ and blocked with normal goat serum for $20 \mathrm{~min}$ at room temperature. After removal of serum, rat monoclonal CD29 antibody (dilution, 1:200; cat. no. 121409), rat monoclonal CD44 antibody (dilution, 1:200; cat. no. 203901) and rat monoclonal CD45 antibody (dilution, 1:200; cat. no. 202211) were added followed by HRP goat anti-rat IgG secondary antibody (dilution, 1:500; cat. no. 405405) (all from BioLegend, Inc., San Diego, CA, USA) after washing with PBS. The cells were stained using AEC staining kit and then haematoxylin. PBS was added for the control group.

In the second experiment, to evaluate the ability of IGF-1 induced BMSCs to transdifferentiate into CLCs, $15 \mathrm{ng} / \mathrm{ml}$ IGF-1 group and control group containing $10 \%$ FCS were used in induction of BMSCs. These cells were observed for morphological changes under an inverted microscope (BX-42; Olympus, Tokyo, Japan). The expression of troponin-T and troponin-I was detected by immunocytochemistry.

In the third experiment, to evaluate the ability of IGF-1 to induce cell recovery from the cytotoxic effects of I-OMe AG538, 2x104/ml cells were plated into $35 \mathrm{~mm}$ culture dish in
DMEM/F12 plus 10\% FCS. After 24 h, 15 ng/ml IGF-1 was added to the medium and $300 \mathrm{nmol} / 1$, replaced by DMEM/F12 plus $10 \% \mathrm{FBS}$ or the compound $(300 \mathrm{nmol} / \mathrm{l})$ every $6 \mathrm{~h} \leq 3$ days. After $72 \mathrm{~h}$ of treatment, the identification of BMSCs by immunocytochemical stain was performed as previously described. The primary antibody was rat monoclonal troponin-T antibody (dilution, 1:500; cat. no. ab50576) and rat polyclonal troponin-I antibody (dilution, 1:500; cat. no. ab47003) (both from Abcam, Cambridge, UK). PBS was used in the control group.

Western blotting. Constitutive activation of IGF-1R was evaluated on a panel of BMSCs. To evaluate the ability of IGF-1 to induce cell recovery from the cytotoxic effects of I-OMe AG538 toward IGF-1R kinase and signaling, starved BMSCs were treated with doses of $300 \mathrm{nmol} / 1$ (corresponding to $\mathrm{IC}_{50}$ value) I-OMe AG538 for $3 \mathrm{~h}$ followed by stimulation with IGF-1 (Peprotech, Inc., Rocky Hill, NJ, USA) for 5 to $30 \mathrm{~min}$. In a second experiment, I-OMe AG538 inhibitory effects were followed on IGF-1R-related signaling pathways by exposing BMSCs to $300 \mathrm{nmol} / \mathrm{l}$ compound for 1 to $48 \mathrm{~h}$ in standard medium. To determine phosphorylation status of Erk1/2 and Akt, two downstream mediators of mitogen-activated protein kinase (MAPK) and phosphatidylinositol 3-kinase (PI3K) pathways, cell lysates were prepared with a buffer containing $50 \mathrm{mmol} / 1 \mathrm{MOPS}, 320 \mathrm{mmol} / 1 \mathrm{Sucrose}, 100 \mathrm{mmol} / 1 \mathrm{Kcl}$, $0.5 \mathrm{mmol} / 1 \mathrm{MgCl}_{2}, 1 \mathrm{mmol} / 1 \mathrm{DTT}, 50 \mathrm{mmol} / 1 \mathrm{NaF}, 20 \mathrm{mmol} / 1$ $\mathrm{NaPPi}, 20 \mathrm{mmol} / \mathrm{l} \beta$-glycerophosphate, $1 \mathrm{mmol} / 1 \mathrm{Na}_{3} \mathrm{VO}_{4}$, $1 \mathrm{mmol} / 1$ EDTA, and protease inhibitors $(0.5 \mathrm{mmol} / 1$ phenylmethylsulfonyl fluoride, $0.5 \mathrm{mmol} / 1$ leupeptin).

In the third experiment, to evaluate the ability of IGF-1 to induce BMSCs to transdifferentiate into CLCs which had been added with $300 \mathrm{nmol} / \mathrm{l}$ I-OMe AG538, we collected BMSCs which were induced by IGF-1 for 3 days. The experiment followed as above. Protein concentration was determined by BCA protein assay (Thermo Labsystems, Santa Rosa, CA, USA) and equivalent amounts of total cell lysate (50 $\mu \mathrm{g})$ were separated by 4 or $10 \%$ SDS-PAGE under denaturing conditions and transferred onto nitrocellulose membrane. Membranes were incubated with $5 \%$ bovine serum albumin confining liquid overnight, then with primary antibodies. Rabbit monoclonal phospho-IGF-1R antibody (dilution, 1:1,000; cat. no. 3918S); rabbit monoclonal IGF-1R antibody (dilution: 1:1,000; cat. no. 14534S); rabbit monoclonal phospho-Akt antibody (dilution, 1:1,000; cat. no. 12178S); rabbit monoclonal Akt antibody (dilution, 1:1,000; cat. no. 11848) and rabbit monoclonal Erk1/2 antibody (dilution, 1:1,000; cat. no. 4348S) were purchased from Cell Signaling Technology, Inc. (Beverly, MA, USA). Then the goat anti-rabbit secondary antibody (dilution, 1:2,000; cat. no. ab6721; Abcam, Cambridge, MA, USA) was added. In all experiments, final concentration of DMSO in the medium was $<0.001 \%$, and in the present study, it had no effect on cell growth inhibition. This method was described by Scotlandi et al (15).

\section{Results}

Morphological changes of BMSCs in vitro. BMSCs were successfully expanded and used for subsequent experiments. At first, single cells of spindle morphology were observed 3-4 days after the initial seeding. The morphologic appearance 

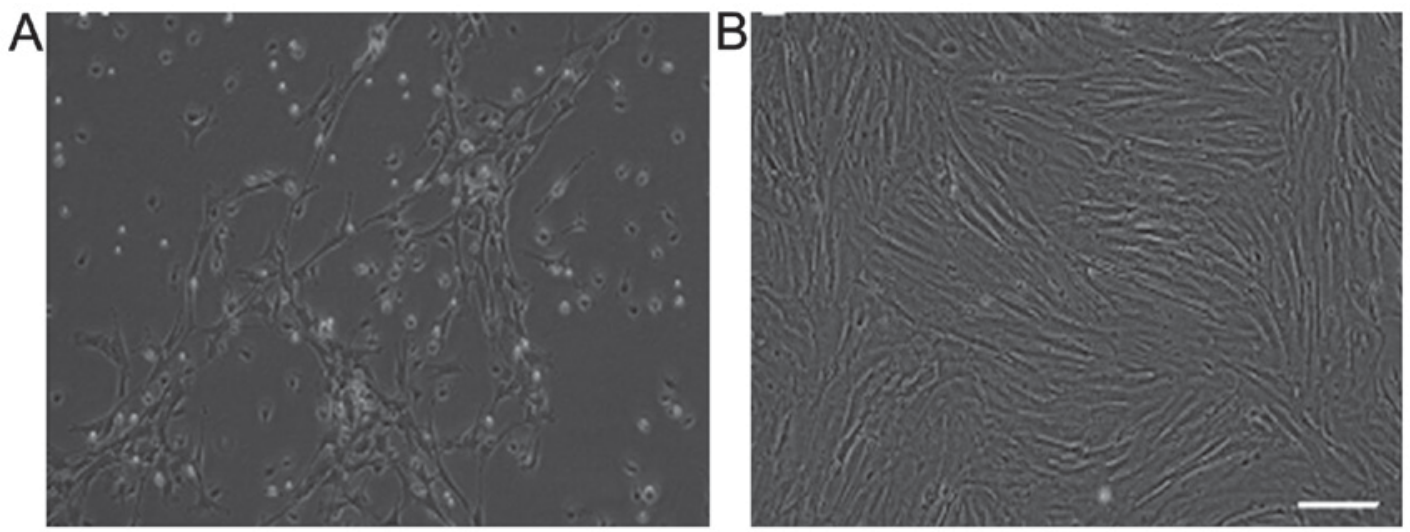

Figure 1. Culturing of bone marrow mesenchymal stem cells (BMSCs). (A) BMSCs became adherent in global, polygon and spindle shaped at 7 days (B) BMSCs were purified, there were no red blood cells in the view and the confluencywas whirlpool-like in passage 6. Scale bar, $100 \mu \mathrm{m}$.
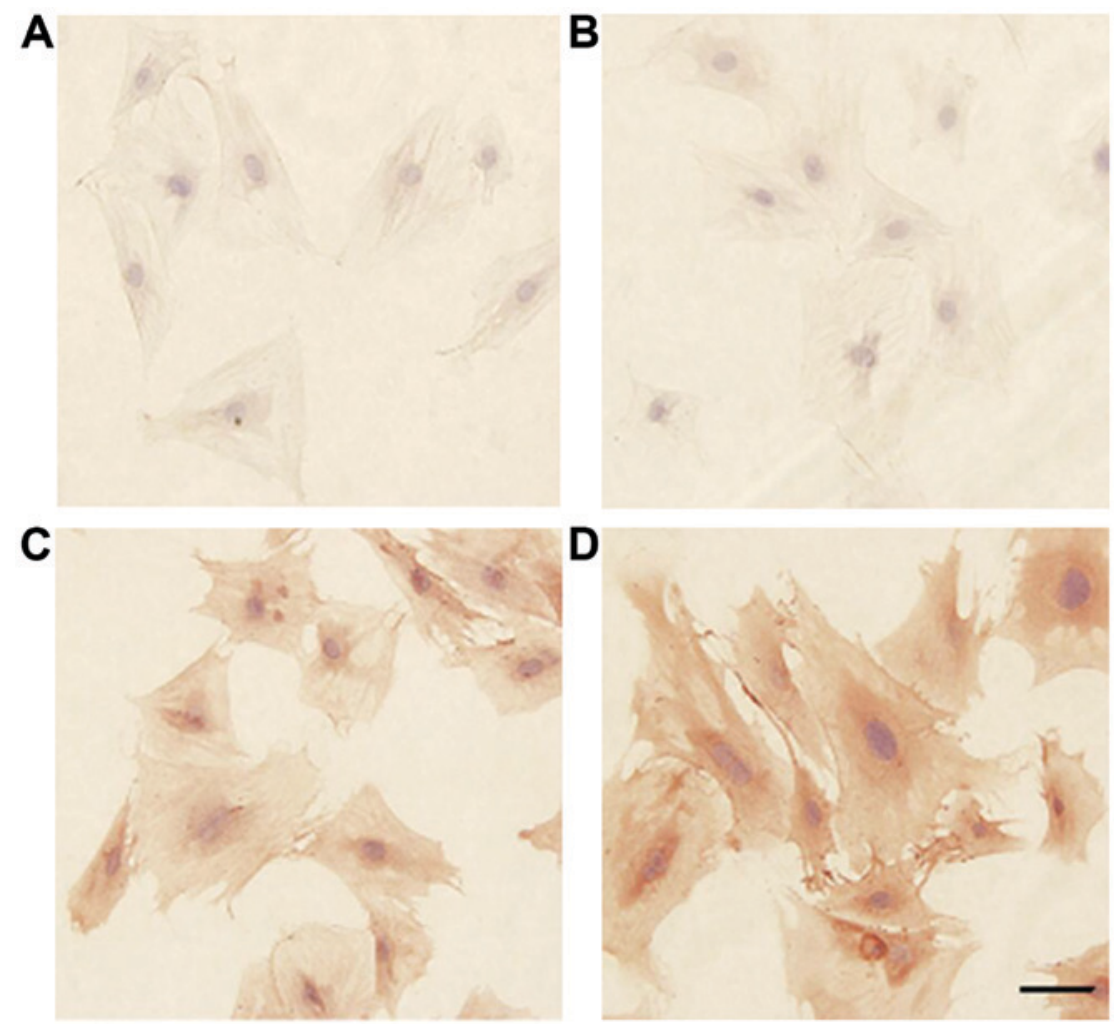

Figure 2. The identification of bone marrow mesenchymal stem cells by immunocytochemical stain. (A) No protein expression in the control group. (B) Negative expression of CD45. (C) Positive expression of CD29. (D) Positive expression of CD44. Scale bar, $50 \mu \mathrm{m}$.

of the cell population was fairly homogeneous (Fig. 1A). About 1 week later, most cells appeared as fibroblasts with spindle or shuttle shape. The colonies continuously grew, reaching $80-90 \%$ confluence in 2 weeks. However, there were some blood cells in the view. When they were labeled at P6, cells were already purified and there were no blood cells in the view and the confluence was whirlpool-like (Fig. 1B).

The identification of BMSCs. All P6 BMSCs express CD29 (Fig. 2C) and CD44 (Fig. 2D), but there was no staining for CD45 (Fig. 2B). This demonstrated that these cells were BMSCs but haemopoietic stem cells. We confirmed that the method to isolate BMSCs was feasible and highly purified cells could be obtained with this method.
The ability of IGF-1 to induce BMSCs to transdifferentiate into CLCs. After BMSCs were exposed to $15 \mathrm{ng} / \mathrm{ml}$ of IGF-1 for 21 days, the morphology of BMSCs did not change. The expression of troponin-T and troponin-I were significantly higher in the 14-day group than control group (Fig. 3) and the levels of pIGF-1R were higher in the 14-day group than other groups (Fig. 4).

I-OMe AG538 selectively inhibits IGF-1-mediated growth and signaling. Fig. 5 demonstrates that similar inhibitory effects were obtained in BMSCs with various concentrations using I-OMe AG538. Growth inhibitory activity of the compound was maintained for $\geq 72 \mathrm{~h}$ after its removal (50\% of growth inhibition with the dose of $331.7 \pm 2.3 \mathrm{nmol} / \mathrm{l}$; $\mathrm{P}<0.05$ ) (Fig. 5). 

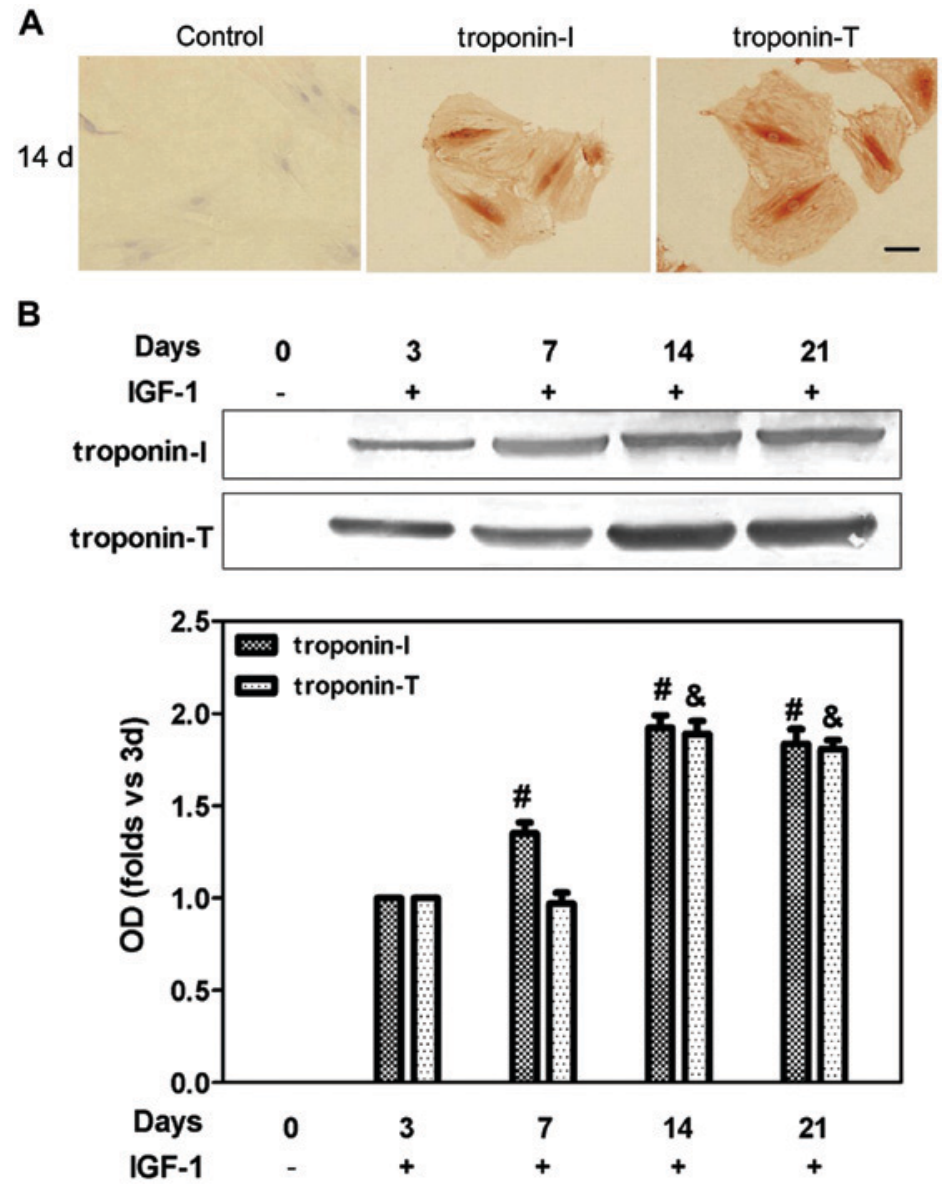

Figure 3. (A) The expression of cardiac tropomyosin-T and cardiac tropomyosin-I for bone marrow mesenchymal stem cells (BMSCs) after induction by IGF-1 for 14 days by immunocytochemistry analysis. Scale bar, $50 \mu \mathrm{m}$. (B) The expression of troponin-T and troponin-I after BMSCs were induced into CLCs by $15 \mathrm{ng} / \mathrm{ml}$ IGF- 1 for 0 to 21 days by western blotting $(\mathrm{n}=3) .{ }^{*}$ Compared with day 3 , tropomyosin-I, $\mathrm{P}<0.05 ;{ }^{\circledR}$ compared with day 3 , tropomyosin-T, $\mathrm{P}<0.05$.
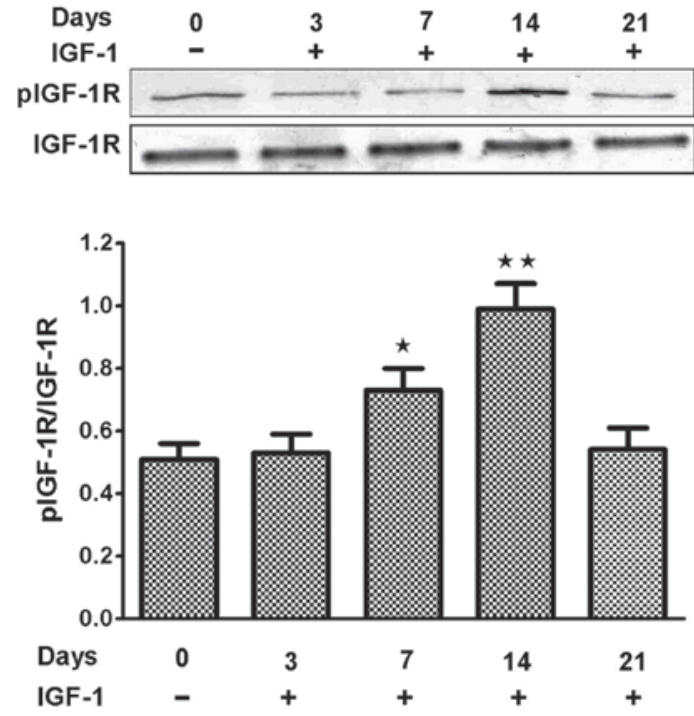

Figure 4. The expression of insulin-like growth factor 1 receptor (IGF-1R) and pIGF-1R after bone marrow mesenchymal stem cells were induced into cardiomyocyte-like cells by $15 \mathrm{ng} / \mathrm{ml}$ IGF-1 for 0 to 21 days. ${ }^{*}$ Compared with day $3, \mathrm{P}<0.05$; ${ }^{* *}$ compared with day $3, \mathrm{P}<0.01$.

To confirm the inhibitory activity of I-OMe AG538 toward IGF-1R kinase and signaling, starved BMSCs were treated with doses of $300 \mathrm{nmol} / \mathrm{l}$ for $3 \mathrm{~h}$ followed by stimulation

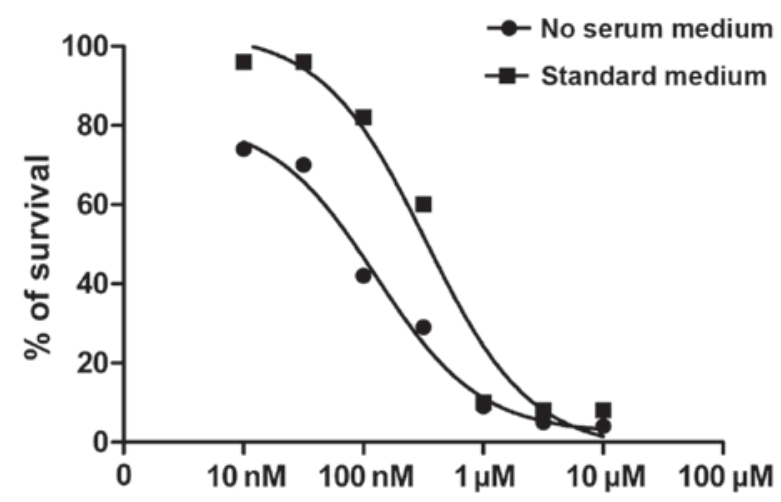

Figure 5. Inhibitory growth effects of I-OMe AG538 (10 nmol/1-100 $\mu \mathrm{mol} / \mathrm{l})$ repeated every $24 \mathrm{~h}$. Cells were harvested at $72 \mathrm{~h}$.

with IGF-1 for 5 to $30 \mathrm{~min}$. Fig. 6 shows that both IGF-1R autophosphorylation and the two major IGF-1R-related intracellular signaling pathways, MAPK and PI3K pathways, were inhibited by I-OMe AG538.

I-OMe AG538 blocks the differentiation into CLCs of BMSCs induced by IGF-1. To confirm the inhibitory activity of I-OMe AG538 and whether it blocks the differentiation of BMSCs into CLCs induced by IGF-1, BMSCs were treated with $15 \mathrm{ng} / \mathrm{ml} \mathrm{IGF-1} \mathrm{and} 300 \mathrm{nmol} / \mathrm{l}$ or $10 \mu \mathrm{mol} / \mathrm{l} \mathrm{I-OMe} \mathrm{AG538.}$ 

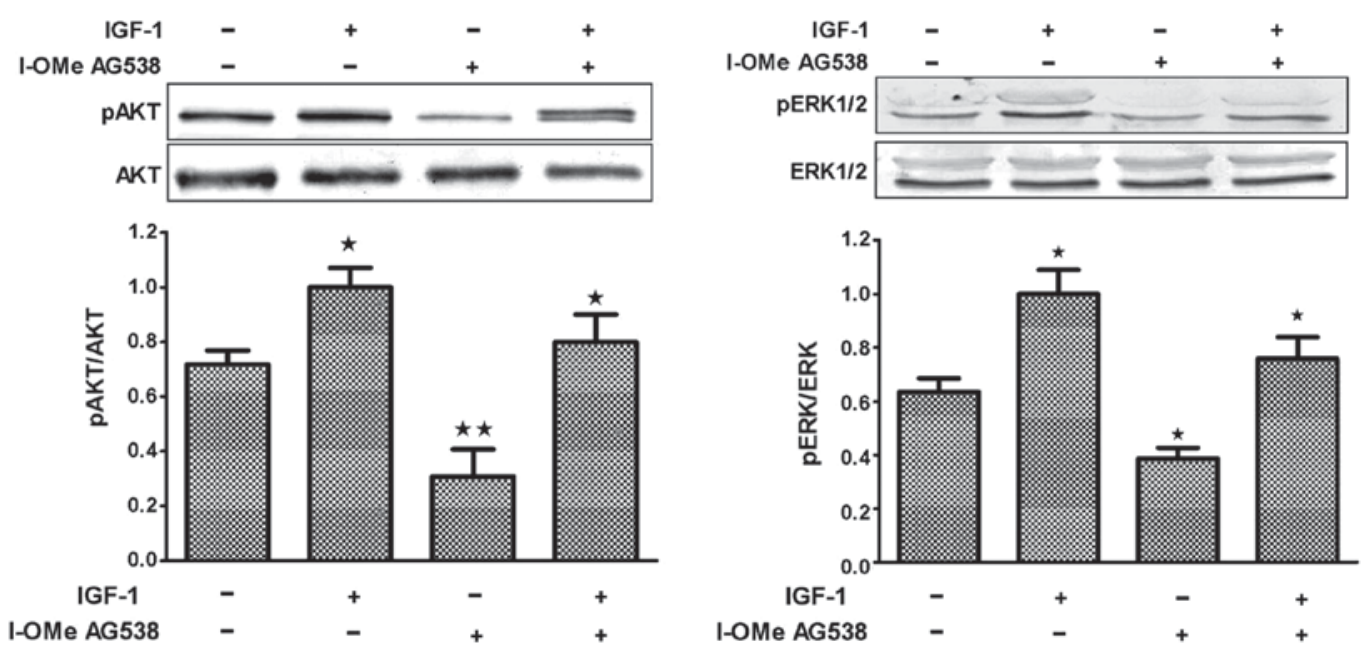

Figure 6. Effects of I-OMe AG538 on IGF-1-mediated receptor activation and cell growth. Starved cells were treated with I-OMe AG538 for $3 \mathrm{~h}$ followed by stimulation with $15 \mathrm{ng} / \mathrm{ml}$ IGF-1 for 5 to $30 \mathrm{~min}$ ( $5 \mathrm{~min}$ for evaluation of MAPK family members Erk1/2 and IGF-1R phosphorylation and 30 min for PI3K mediator Akt activation). IGF-1R was immunoprecipitated and blotted with an anti-phospho-tyrosine antibody to visualize its level of tyrosine phosphorylation. Erk1/2 and Akt phosphorylation was immunodetected with specific antibodies on whole cell lysates. Anti-Akt, anti-Erk1/2 or anti-IGF-1R antibodies

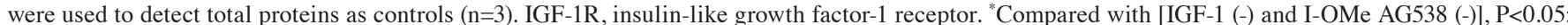
** compared with [IGF-1 (-) and I-OMe AG538 (-)], P<0.01.

A

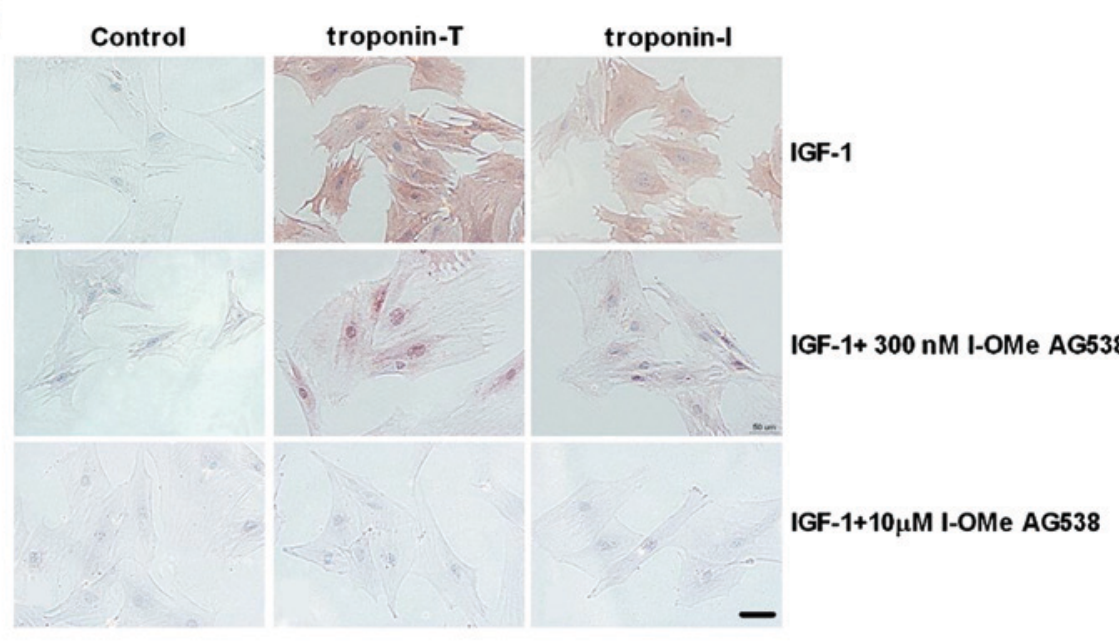

B

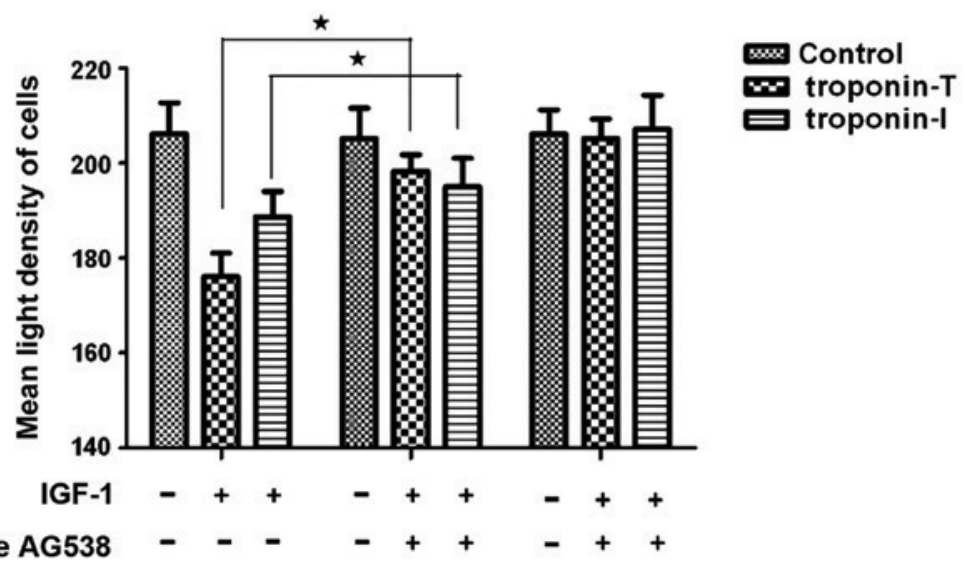

Figure 7. Expression of myocardium marker of troponin-T and troponin-I after bone marrow mesenchymal stem cells were added $15 \mathrm{ng} / \mathrm{ml}$ insulin-like growth factor-1 (IGF-1) and $300 \mathrm{nmol} / 1$ and $10 \mu \mathrm{mol} / \mathrm{l} \mathrm{I}-\mathrm{OMe}$ AG538 for 3 days by (A) immunocytochemistry (scale bar, $50 \mu \mathrm{m}$ ) and (B) western blotting (n=3). ${ }^{*} \mathrm{P}<0.05$.

Fig. 7 shows that the expression of troponin-T and troponin-I were inhibited by $300 \mathrm{nmol} / \mathrm{l}$ I-OMe AG538.
In vitro activity of I-OMe AG538 on BMSCs. A time course evaluation of inhibitory effects of $300 \mathrm{nmol} / 1$ 

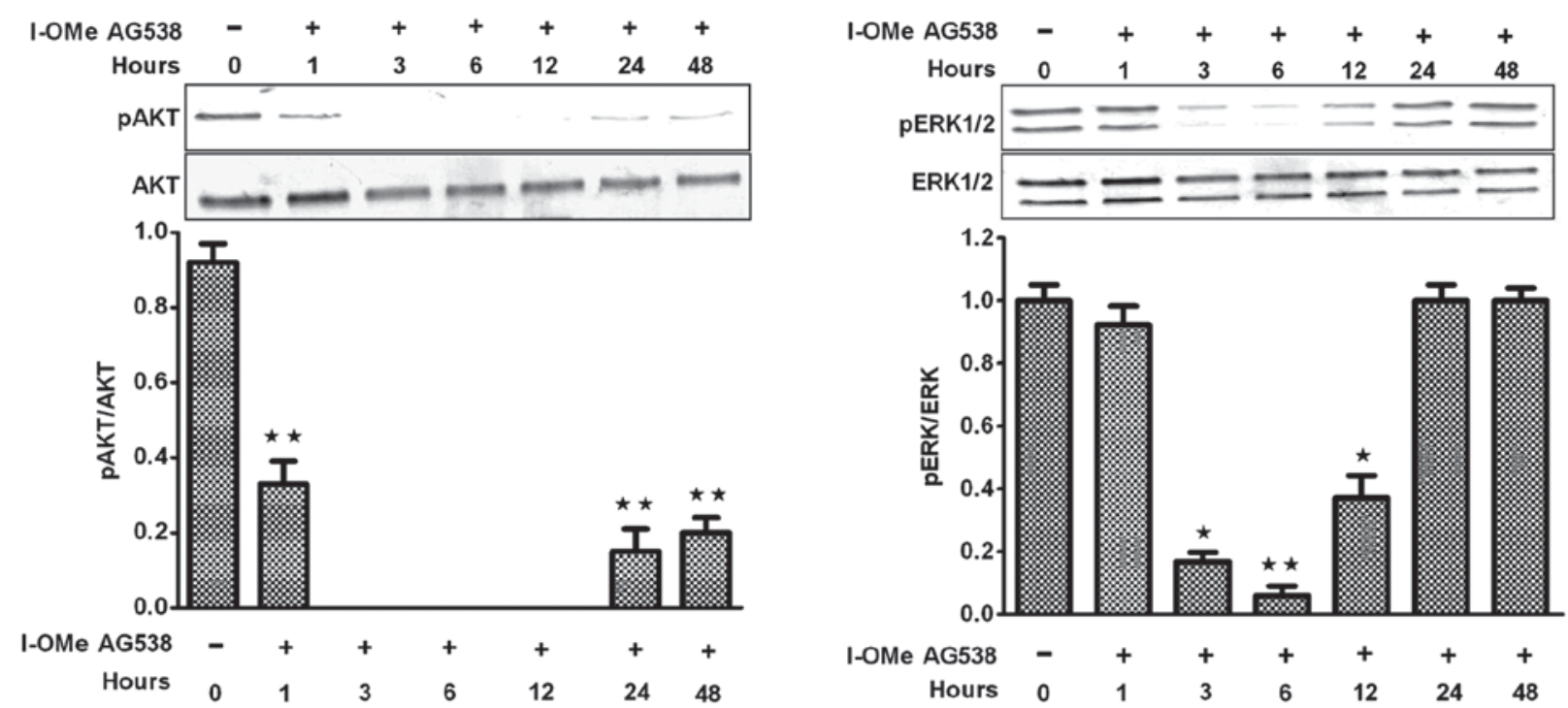

Figure 8. Time course inhibitory effects of I-OMe AG538 on MAPK family members Erk1/2 and PI3K mediator Akt activation in bone marrow mesenchymal stem cells cultured in standard medium in the presence of $300 \mathrm{nmol} / 1 \mathrm{I}-\mathrm{OMe}$ AG538. Cells were analyzed by immunoblotting. Erk1/2 and Akt phosphorylation was probed with specific antibodies. Anti-Akt or anti-Erk1/2 antibodies were used to detect total proteins as controls $(\mathrm{n}=3)$. ${ }^{*}$ Compared with hour $0, \mathrm{P}<0.05$; *** compared with hour $0, \mathrm{P}<0.01$.

I-OMe AG538 on MAPK and PI3K signaling pathways in standard medium, however, revealed transient effects on MAPK and PI3K pathway, particularly for the dose of $300 \mathrm{nmol} / \mathrm{l}$ (Fig. 8)

\section{Discussion}

The traditional belief has been that the cardiac muscle is a terminally differentiated tissue and can only be replaced by scar tissue after a myocardial infarction. To maintain cardiac pumping following an infarction, remodeling of the degenerative left ventricle occurs, causing a decrease in cardiac function and leading to heart failure (4). BMSCs have been considered to be one of the potential cell sources for cellular cardiomyoplasty due to their multipotency and immunomodulatory properties $(2,16,17)$. Although there is great enthusiasm for repairing the heart by using cell therapy, simple cell implantation cannot reinstate cell transdifferentiation or reverse apoptosis. Furthermore, experimental data indicate that only a small number of cells can be implanted in the host tissue with normal function. Therefore, attempts at using various approaches to enhance the effectiveness of cell therapy have become a challenge (16). However, utilizing growth factors in a local tissue environment to increase the survival of transplanted cells may be practical. IGF-1 has been considered as a potent growth hormone capable of inducing cell proliferation, limiting apoptotic cell death, and attenuating maladaptive extracellular matrix remodeling in the failing heart $(17,18)$. IGF-1 can promote angiogenesis in the infarcted myocardium, reduce the degree of myocardial necrosis, maintain the myocardial structure, stimulate proliferation of cardiac fibroblast and inhibit matrix degradation. Thus, IGF-1 can prevent ventricular dilatation and reduce load capacity of the heart (19-21). IGF-1 plays an important role in proliferation and differentiation of stem cells. It has been reported that IGF-1 promotes migration of endothelial cells and cardiac resident progenitor cells (10-12). A recent report also found that IGF-1 increases BMSCs migratory responses in vitro via CXCR4 chemokine receptor signaling and provided substantial evidence that PI3-kinase/Akt is the dominant signaling pathway underlying IGF-1 enhanced BMSCs migration (22). Kofidis et al (23) found that insulin-like growth factor promotes engraftment, differentiation, and functional improvement after transfer of embryonic stem cells for myocardial restoration.

IGF-1R is the most important individual component of the IGF axis that includes the ligands IGF-1 and IGF-2, six high-affinity IGF-binding proteins, several proteases, and three receptors (24). In general, the activation of IGF/IGF-1R signaling promotes proliferative and survival mechanisms that can be usefully exploited by many cells (25).

In the present study, in order to determine whether $15 \mathrm{ng} / \mathrm{ml}$ IGF-1 could induce BMSCs to transdifferentiate into CLCs and have a heart cell phenotype, cells were treated with antibodies against proteins expressed in cardiac cells, including troponin-T and troponin-I. After BMSCs were exposed to $15 \mathrm{ng} / \mathrm{ml}$ IGF-1 for 21 days, the morphology of BMSCs did not change. Immunocytochemistry analysis and western blotting all showed that the expression of troponin-T and troponin-I were significantly higher in the 14 day group than control group and the level of pIGF-1R was also higher in 14 day group than the control group. These results suggested that IGF-1 could induce BMSCs to transdifferentiate into CLCs and have a heart cell phenotype.

IGF-1R kinase inhibitor I-OMe AG538 were added to detect if I-OMe AG538 could inhibit IGF-1-mediated receptor activation and downstream signaling. Our data showed that I-OMe AG538 was found to fulfill the key features expected from an IGF-1R inhibitor. It selectively inhibits IGF-1-mediated growth and signal transduction in BMSCs. Of note, the inhibitory effects of I-OMe AG538 were not completely reverted in the presence of $15 \mathrm{ng} / \mathrm{ml} \mathrm{IGF-1.} \mathrm{BMSCs}$ are sensitive to I-OMe AG538 and therefore, when a time course analysis of the 
effects of I-OMe AG538 on MAPK and PI3K signaling was done, we observed a transient inhibitory effect on Erk1/2 and Akt phosphorylation, which is in keeping with the inhibitory effects on cell growth.

In conclusion, BMSCs can transdifferentiate into CLCs and obtain the myocardial cell phenotype in the presence of IGF-1 (13). In addition, the induction effects of IGF-1 can be blocked by the inhibitor of IGF-1R kinase and be timedependent. However, as we know, PI3K/Akt is the dominant signaling pathway underlying IGF-1 enhanced cell survival and migration $(22,26)$, and the Ras/Raf/MEK/ERK MAPK pathway regulates the expression of a large number of proteins involved in the control of cell proliferation, differentiation, and apoptosis $(27,28)$. Therefore, if the effect that IGF-1 induces BMSCs to transdifferentiate into CLCs is through the MAPK/ERK pathway, then that needs to be further studied.

\section{Acknowledgements}

This study was supported by the National Nature Science Foundation of China (grant no. 30572073); the Life Health Science and Technology Projects funded by the Jiangsu Special Funds (grant no. BL2012019); the Jiangsu Key Talents of Medical Science (grant no. RC2007024); the Xuzhou Science and Technology Development Project (grant no. XF10C029); and the Xuzhou Science and Technology Development Project (grant no. XM12B062).

\section{References}

1. Liechty KW, MacKenzie TC, Shaaban AF, Radu A, Moseley AM, Deans R, Marshak DR and Flake AW: Human mesenchymal stem cells engraft and demonstrate site-specific differentiation after in utero transplantation in sheep. Nat Med 6: 1282-1286, 2000.

2. Orlic D, Kajstura J, Chimenti S, Limana F, Jakoniuk I, Quaini F, Nadal-Ginard B, Bodine DM, Leri A and Anversa P: Mobilized bone marrow cells repair the infarcted heart, improving function and survival. Proc Natl Acad Sci USA 98: 10344-10349, 2001.

3. Kudo M, Wang Y, Wani MA, Xu M, Ayub A and Ashraf M: Implantation of bone marrow stem cells reduces the infarction and fibrosis in ischemic mouse heart. J Mol Cell Cardiol 35: 1113-1119, 2003.

4. Li Z, Gu TX and Zhang YH: Hepatocyte growth factor combined with insulin like growth factor-1 improves expression of GATA-4 in mesenchymal stem cells cocultured with cardiomyocytes Chin Med J (Engl) 121: 336-340, 2008.

5. Rangappa S, Entwistle JW, Wechsler AS and Kresh JY: Cardiomyocyte-mediated contact programs human mesenchymal stem cells to express cardiogenic phenotype. J Thorac Cardiovasc Surg 126: 124-132, 2003.

6. Haylor J, Hickling H, El Eter E, Moir A, Oldroyd S, Hardisty C and El Nahas AM: JB3, an IGF-I receptor antagonist, inhibits early renal growth in diabetic and uninephrectomized rats. J Am Soc Nephrol 11: 2027-2035, 2000.

7. Hu C, Wu Y, Wan Y, Wang Q and Song J: Introduction of hIGF-1 gene into bone marrow stromal cells and its effects on the cell's biological behaviors. Cell Transplant 17: 1067-1081, 2008.

8. Schnabel LV, Lynch ME, van der Meulen MC, Yeager AE, Kornatowski MA and Nixon AJ: Mesenchymal stem cells and insulin-like growth factor-I gene-enhanced mesenchymal stem cells improve structural aspects of healing in equine flexor digitorum superficialis tendons. J Orthop Res 27: 1392-1398, 2009.

9. Blum G, Gazit A and Levitzki A: Substrate competitive inhibitors of IGF-1 receptor kinase. Biochemistry 39: 15705-15712, 2000.
10. Urbich C, Aicher A, Heeschen C, Dernbach E, Hofmann WK, Zeiher AM and Dimmeler S: Soluble factors released by endothelial progenitor cells promote migration of endothelial cells and cardiac resident progenitor cells. J Mol Cell Cardiol 39: 733-742, 2005.

11. Xu M, Uemura R, Dai Y, Wang Y, Pasha Z and Ashraf M: In vitro and in vivo effects of bone marrow stem cells on cardiac structure and function. J Mol Cell Cardiol 42: 441-448, 2007.

12. Su EJ, Cioffi CL, Stefansson S, Mittereder N, Garay M, Hreniuk D and Liau G: Gene therapy vector-mediated expression of insulin-like growth factors protects cardiomyocytes from apoptosis and enhances neovascularization. Am J Physiol Heart Circ Physiol 284: H1429-H1440, 2003.

13. Guo J, Lin G, Bao C, Hu Z, Chu H and $\mathrm{Hu}$ M: Insulin-like growth factor 1 improves the efficacy of mesenchymal stem cells transplantation in a rat model of myocardial infarction. J Biomed Sci 15: 89-97, 2008.

14. Panepucci RA, Siufi JL, Silva WA Jr, Proto-Siquiera R, Neder L, Orellana M, Rocha V, Covas DT and Zago MA: Comparison of gene expression of umbilical cord vein and bone marrow-derived mesenchymal stem cells. Stem Cells 22: 1263-1278, 2004.

15. Scotlandi K, Manara MC, Nicoletti G, Lollini PL, Lukas S, Benini S, Croci S, Perdichizzi S, Zambelli D, Serra M, et al: Antitumor activity of the insulin-like growth factor-I receptor kinase inhibitor NVP-AEW541 in musculoskeletal tumors. Cancer Res 65: 3868-3876, 2005.

16. Shake JG, Gruber PJ, Baumgartner WA, Senechal G, Meyers J, Redmond JM, Pittenger MF and Martin BJ: Mesenchymal stem cell implantation in a swine myocardial infarct model: Engraftment and functional effects. Ann Thorac Surg 73: 1919-1925, discussion 1926, 2002.

17. Li G, Borger MA, Williams WG, Weisel RD, Mickle DA, Wigle ED and Li RK: Regional overexpression of insulin-like growth factor-I and transforming growth factor-beta1 in the myocardium of patients with hypertrophic obstructive cardiomyopathy. J Thorac Cardiovasc Surg 123: 89-95, 2002.

18. Welch S, Plank D, Witt S, Glascock B, Schaefer E, Chimenti S, Andreoli AM, Limana F, Leri A, Kajstura J, et al: Cardiac-specific IGF-1 expression attenuates dilated cardiomyopathy in tropomodulin-overexpressing transgenic mice. Circ Res 90: 641-648, 2002.

19. Bayes-Genis A, Conover CA and Schwartz RS: The insulin-like growth factor axis: A review of atherosclerosis and restenosis. Circ Res 86: 125-130, 2000.

20. Beamer WG, Donahue LR and Rosen CJ: Insulin-like growth factor I and bone: From mouse to man. Growth Horm IGF Res 10: S103-S105, 2000.

21. Madry H, Zurakowski D and Trippel SB: Overexpression of human insulin-like growth factor-I promotes new tissue formation in an ex vivo model of articular chondrocyte transplantation. Gene Ther 8: 1443-1449, 2001.

22. Li Y, Yu X, Lin S, Li X, Zhang S and Song YH: Insulin-like growth factor 1 enhances the migratory capacity of mesenchymal stem cells. Biochem Biophys Res Commun 356: 780-784, 2007.

23. Kofidis T, de Bruin JL, Yamane T, Balsam LB, Lebl DR, Swijnenburg RJ, Tanaka M, Weissman IL and Robbins RC: Insulin-like growth factor promotes engraftment, differentiation, and functional improvement after transfer of embryonic stem cells for myocardial restoration. Stem Cells 22: 1239-1245, 2004.

24. Larsson O, Girnita A and Girnita L: Role of insulin-like growth factor 1 receptor signalling in cancer. Br J Cancer 92: 2097-2101, 2005.

25. Pollak MN, Schernhammer ES and Hankinson SE: Insulin-like growth factors and neoplasia. Nat Rev Cancer 4: 505-518, 2004.

26. McMahon LA, Prendergast PJ and Campbell VA: A comparison of the involvement of $\mathrm{p} 38, \mathrm{ERK} 1 / 2$ and PI3K in growth factor-induced chondrogenic differentiation of mesenchymal stem cells. Biochem Biophys Res Commun 368: 990-995, 2008.

27. Peyssonnaux $C$ and Eychène $A$ : The Raf/MEK/ERK pathway: New concepts of activation. Biol Cell 93: 53-62, 2001.

28. Wong KK: Recent developments in anti-cancer agents targeting the Ras/Raf/ MEK/ERK pathway. Recent Patents Anticancer Drug Discov 4: 28-35, 2009. 